Artikel Penelitian

\title{
Analisis HKSA Senyawa Antidiabetik Turunan Triazolopiperazin Amida Menggunakan Metode Semiempirik PM3
}

\author{
Anjar Purba Asmara1 ${ }^{1}$, Mudasir ${ }^{2}$, Dwi Siswanta² \\ ${ }_{1}^{1}$ Program Studi Kimia, Fakultas Sains dan Teknologi, UIN Ar-Raniry, Banda Aceh \\ ${ }^{2}$ Departemen Kimia, Fakultas Matematika dan IImu Pengetahuan Alam, UGM, Yogyakarta
}

\section{INFO ARTIKEL}

Sejarah artikel:

Revisi 24 September 2017

Diterima 30 Oktober 2017

Tersedia online 16 Januari 2018

*Penulis korespondensi

Email : anjarpurbaasmara@gmail.com

\section{ABSTRAK}

An analysis of quantitative of structure and activity relationship (QSAR) has been conducted to triazolopiperazine amide derivatives which used to inhibit DPP IV enzyme related to diabetes mellitus type 2 (T2DM). It has been done by the molecular modeling and descriptors computing with semiempirical PM3 method which operated in Hyperchem 8.0. The quantitative data of electronic and molecular parameter was analyzed by multilinear regression method which ran in SPSS 13. As the result, here is the best equation for the molecule which shown as following as:

$\log \mathrm{IC}_{50}=79.955-\left(11.635^{*} \mathrm{qC} 1\right)-\left(2.094^{*} \mathrm{qC} 2\right)-\left(34.6^{*} \mathrm{qN} 11\right)+$ $\left(797.684^{*} \mathrm{qC} 15\right)+\left(0.288^{*} \mu\right)$

$n=18 ; r=0.714 ;$ adjusted $r^{2}=0.305 ; F_{\text {hit }} F_{\text {tab }}=1.239 ;$ PRESS $=0.017$.

By using the equation, this work has proposed a new derivative compound with the value of $-\log \mathrm{IC}_{50}$ as 8.601 namely: ((2R)-4-0xo-4-[3(Trifluoromethyl)-5,6-dihydro[1,2,4]triazolo[4,3-a]pirazine-7(8H)-yl]-1-(2fluoro-4,6-dihydroxophenyl)butane-2-amine

Keywords: QSAR, triazolopiperazine amide, DPP IV, PM3, T2DM

Kajian tentang hubungan kuantitatif struktur dan aktivitas (HKSA) telah digunakan untuk analisis senyawa turunan triazolopiperazin amida sebagai inhibitor enzim DPP IV, salah satu enzim yang berhubungan dengan diabetes melitus tipe 2. Analisis ini dilakukan dengan pemodelan molekul dan perhitungan deskriptor HKSA menggunakan metode semiempirik PM3 dengan program Hyperchem 8.0. Data parameter elektronik dan molekular dianalisis dengan metode regresi multilinear menggunakan program SPSS 13. Model terbaik diusulkan dengan persamaan berikut:

$-\log \mathrm{IC}_{50}=79,955-\left(11,635^{*} \mathrm{qC} 1\right)-\left(2,094^{*} \mathrm{qC} 2\right)-\left(34,6^{*} \mathrm{qN} 11\right)+$ $\left(797,684^{*} \mathrm{qC} 15\right)+\left(0,288^{*} \mu\right)$

$n=18 ; r=0,714 ;$ adjusted $r^{2}=0,305 ; F_{\text {hit }} F_{\text {tab }}=1,239 ;$ PRESS $=0,017$.

Berdasarkan persamaan tersebut, senyawa dengan aktivitas terbaik yang diusulkan adalah:

((2R)-4-okso-4-[3-(trifluorometil)-5,6-dihidro[1,2,4]triazolo[4,3-a]pirazin-7(8H)il]-1-(2-fluoro-4,6-dihidroksofenil)butan-2-amina

dengan harga $-\log \mathrm{IC}_{50}=8,601$.

Kata Kunci: HKSA, triazolopiperazin amida, DPP IV, PM3, T2DM 


\section{Pendahuluan}

Penyakit gula atau diabetes mellitus merupakan salah satu penyakit mematikan di dunia. Penyakit ini diklasifikasikan menjadi dua tipe, tipe 1 karena defisiensi produksi insulin dan tipe 2 karena resistensi penggunaan insulin (Gardner \& Shoback, 2011). Sekitar $90 \%$ dari 285 juta orang penderita diabetes di dunia adalah penderita diabetes jenis 2 pada tahun 2010 (Lambert \& Bingley, 2002) yang disebabkan oleh pola hidup yang tidak sehat. Jumlah ini diperkirakan akan meningkat menjadi hampir dua kali lipatnya pada tahun 2030 (Wild, Roglic, Green, Sicree \& King, 2004).

Dalam metabolisme glukosa tubuh, enzim DPP IV atau protein kompleks adenosin deaminase 2 berperan penting dalam kontrol sekresi insulin. Kinerjanya dengan mendegradasi hormon pemacu produksi insulin dalam usus seperti GLP-1 dan GIP (Vilsbøll, Hare, Bagger \& Knop, 2009). Enzim DPP IV menonaktifkan hormon GLP-1 dan GIP dengan memotong ikatan $\mathrm{N}$-penghubung dari dua asam aminonya (Kowalchick et al., 2007).

Aktivitas DPP IV secara cepat, meluas, dan tak terkendali menyebabkan gangguan metabolisme glukosa karena produksi insulin menjadi kurang. Hasilnya adalah tubuh akan mengalami hiperglikemia. Dengan diketahuinya peran enzim ini, penelitian tentang pengembangan senyawa obat antidiabetik terdorong untuk melakukan penghambatan DPP IV agar sirkulasi endogen GLP-1 dan aktivitas insulinotropik dari GIP meningkatkan. Selama ini, senyawa obat inhibitor DPP IV dibagi menjadi dua golongan, yaitu: substrate-like inhibitor (sianopirolidin, vidagliptin, dan saksagliptin) dan nonsubstrate-like inhibitor (sitagliptin dan alogliptin) (Monika, Sarbjot, \& Punam, 2009).

Salah satu senyawa inhibitor DPP IV adalah sitagliptin. Obat ini dipasarkan pada tahun 2007 dengan merk Januvia ${ }^{\circledR}$ oleh Merck Ltd. Sitagliptin memiliki durasi aksi yang lama yaitu dengan dosis satu kali dalam sehari mampu menghambat 70 90\% aktivitas DPP IV dalam 24 jam sehingga mampu melindungi hormon inkresi endogen dari degradasi (Vilsbøll, et al., 2009).

Sitagliptin merupakan salah satu senyawa turunan triazolopiperazin amida dengan karakteristik farmakokinetik yang sangat memuaskan (Monika et al., 2009). Saqib \& Siddiqi (2009) telah melakukan kajia HKSA 3 dimensi terhadap senyawa turunan triazolopiperzin amida melalui korelasi struktur dan sifat deskriptornya dengan aktivitas eksperimentalnya. Deskriptor fisikokimia menjadi parameter untuk menghitung hidrofobisitas, topologi, sifat elektronik, dan efek sterik secara komputasional. Penelitian ini bermanfaat bagi pengembangan dan modifikasi struktur senyawa inhibitor selanjutnya. Asmara, Mudasir, \& Siswanta (2013) telah melakukan penelitian pemodelan senyawa ini menggunakan metode semiempirik AM1 namun perlu divariasi dengan metode semiempirik PM3 yang memiliki tingkat keakuratan yang memuaskan dalam pemodelan senyawa obat.

Penelitian ini bertujuan untuk menganalisis dan memodifikasi struktur senyawa turunan triazolopiperazin amida yang sebelumnya telah dianalisis dengan metode AM1. Penelitian ini fokus pada analisis deskriptor elektronik yang dihitung dengan metode semiempirik PM3. Data hasil perhitungan komputasi selanjutnya dianalisis secara statistik dengan analisis regresi multilinear yang tepat untuk data deskriptor yang banyak.

\section{Bahan dan metode}

\subsection{Bahan}

Penelitian ini menggunakan perangkat komputer dengan procesor Intel Pentium $43 \mathrm{GHz}$, RAM 512 GB, Harddisk 60 GB. Perangkat lunak yang digunakan adalah Hyperchem 8.0 untuk pemodelan molekul dan SPSS 13 untuk analisis persamaan HKSA. Seluruh penelitian dilakukan di Austrian-Indonesian Centre (AIC) for Computational Chemistry Jurusan Kimia, FMIPA Universitas Gadjah Mada. Penelitian ini menggunakan data struktur dan bioaktivitas dari senyawa turunan triazolopiperazin amida secara eksperimen yang diujikan pada tikus yang ditunjukkan pada Tabel 1 (Saqib \& Siddiqi, 2009; Kim et al, 2005).

\subsection{Validasi metode}

Penentuan metode yang lebih layak untuk optimasi senyawa turunan triazolopiperazin amida dilakukan dengan cara membandingkan perhitungan keempat metode semiempirik dengan metode ab initio. Metode mekanika kuantum ab initio menghitung struktur molekul dengan melibatkan seluruh elektron yang berada pada kulit atom dari suatu atom. Metode ini relatif lebih lama dalam pengoperasiannya. Namun, hasil 
perhitungannya sangat akurat dan mendekati data yang sebenarnya. sesuai dengan senyawa sebenarnya (Pranowo, 2003).

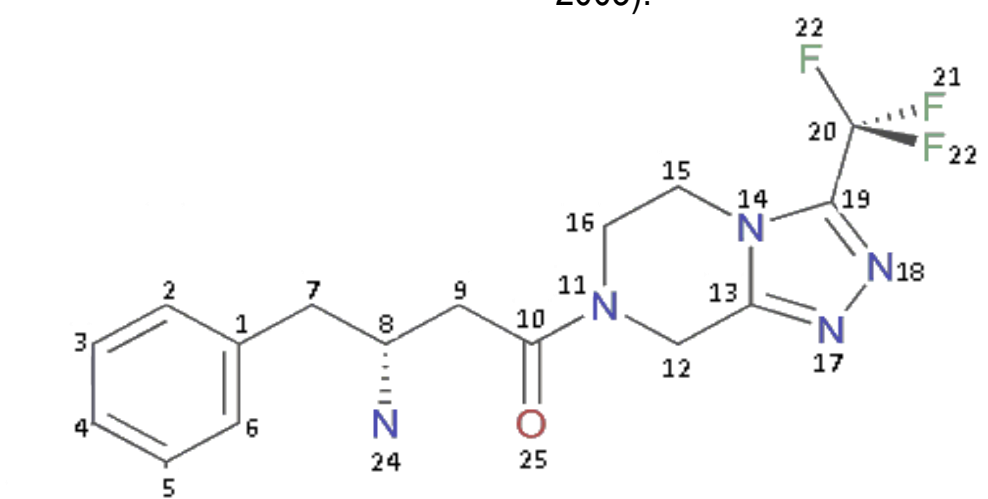

Gambar 1. Struktur senyawa induk triazolopiperazin amida (Saqib \& Shidiqqi, 2009)

Tabel 1.

Nama senyawa dan aktivitas senyawa turunan triazolopiperazin amida (Kim et al., 2005)

\begin{tabular}{ccc}
\hline No & $\mathbf{R}$ & $-\log \mathbf{I}_{50}$ \\
\hline $\mathbf{1}$ & $2-\mathrm{F}$ & 7,0 \\
$\mathbf{2}$ & $3-\mathrm{F}$ & 6,9 \\
$\mathbf{3}^{*}$ & $4-\mathrm{F}$ & 6,6 \\
$\mathbf{4}$ & $3,4-\mathrm{F}$ & 6,9 \\
$\mathbf{5}^{*}$ & $2,4-\mathrm{F}$ & 7,1 \\
$\mathbf{6}$ & $2,5-\mathrm{F}$ & 7,57 \\
$\mathbf{7}$ & $2,3,5-\mathrm{F}$ & 6,1 \\
$\mathbf{8}$ & $2,3,6-\mathrm{F}$ & 6,8 \\
$\mathbf{9}$ & $2,4,5-\mathrm{F}$ & 7,74 \\
$\mathbf{1 0}$ & $2,4,6-\mathrm{F}$ & 7,1 \\
$\mathbf{1 1}$ & $2,3,4,5,6-\mathrm{F}$ & 6,0 \\
$\mathbf{1 2}$ & $2-\mathrm{CF}$ & 6,3 \\
$\mathbf{1 3}$ & $3-\mathrm{CF}$ & 6,4 \\
$\mathbf{1 4}$ & $4-\mathrm{CF}$ & 6,3 \\
$\mathbf{1 5}$ & $2-\mathrm{Cl}$ & 6,8 \\
$\mathbf{1 6}$ & $3-\mathrm{Cl}$ & 7,2 \\
$\mathbf{1 7}$ & $4-\mathrm{Cl}$ & 6,6 \\
$\mathbf{1 8}$ & $3,4-\mathrm{Cl}$ & 5,8 \\
$\mathbf{1 9}$ & $2,4-\mathrm{Cl}$ & 7,63 \\
$\mathbf{2 0}$ & $2,5-\mathrm{Cl}$ & 6,7 \\
$\mathbf{2 1}$ & $2-\mathrm{F}, 5-\mathrm{Cl}$ & 7,7 \\
$\mathbf{2 2}$ & $2,5-\mathrm{F}, 4-\mathrm{Cl}$ & 7,1 \\
$\mathbf{2 3}$ & $2-\mathrm{Cl}, 4,5-\mathrm{F}$ & 7,1 \\
\hline
\end{tabular}

Metode mekanika kuantum semiempirik dijalankan dengan lebih cepat karena tidak semua persamaan diselesaikan secara eksak dan elektron yang diperhitungkan hanyalah elektron valensinya saja. Data hasil perhitungannya tidak seteliti perhitungan dengan metode ab initio. Oleh karena itu, hasil perhitungan metode semiempirik ini diparameterisasi dengan data dari perhitungan metode $a b$ initio. Parameterisasi ini bertujuan untuk memilih jenis metode semiempirik yang tepat untuk senyawa yang dianalisis agar mendekati data yang
Dengan pertimbangan-pertimbangan tersebut, validasi pemodelan dalam penelitian ini dilakukan dengan cara menghitung besarnya panjang ikatan, sudut ikatan antaratom, dan muatan bersih atom dengan metode CNDO, MNDO, AM1, dan PM3 yang dibandingkan dengan hasil perhitungan metode ab initio yang lebih akurat. Perhitungan dilakukan hanya pada atom-atom rantai utama senyawa induk triazolopiperazin amida sebelum tersubstitusi. Atom-atom yang dimaksud adalah atom $\mathrm{C}$, $\mathrm{C} 8, \mathrm{C}$, dan $\mathrm{C} 10$ seperti yang ditunjukkan pada Gambar 1.

\subsection{Optimasi struktur molekul}

Struktur molekul digambar secara langsung di Hyperchem 8.0 lalu pilih add hydrogen and model build. Perhitungan dimulai dengan memilih metode semi-empirik tervalid lalu pilih menu geometry optimization untuk optimasi strukturnya. Perhitungan single point dengan output data file.log dilakukan dengan memiliki menu start log pada Edit. Data yang dihasilkan adalah energi dan muatan bersih atom. Data yang lain seperti luas permukaan, polarisabilitas molekul, muatan atom parsial, energi hidrasi, volume, log $P$, massa molekul, dan refraktivitas molar diperoleh dari menu QSAR properties.

\subsection{Analisis HKSA}

Data parameter elektronik dan molekuler dari senyawa fitting (senyawa selain no $3,5,17$, dan 20) digunakan untuk analisis HKSA. Analisis regresi multilinear dilakukan untuk mendapatkan model persamaan HKSA menggunakan metode enter dan backward. Variabel bebasnya adalah parameter elektronik dan molekular yang meliputi muatan bersih atom (q), $\log P$, momen dipol $(\mu)$, 
energi hidrasi $\left(E_{H}\right)$, energi atomik terisolasi $\left(E_{\text {at.is }}\right)$, energi total $\left(E_{T}\right)$, energi ikatan $\left(E_{b}\right)$, energi elektronik $\left(E_{e}\right)$, panas pembentukan $\left(\Delta H_{f}\right)$ luas permukaan $(\mathrm{SA})$, volume $(\mathrm{V})$, massa molekular $(\mathrm{MW})$, interaksi inti-inti $\left(\mathrm{E}_{\text {int }}\right)$, refraktivitas molar (RM), dan polarisabilitas molekul (a). Variabel terikatnya adalah bioaktivitas senyawa turunan triazolopiperazin amida yang dinyatakan dalam -log $\mathrm{IC}_{50}$.

Penentuan kandidat model persamaan HKSA yang terbaik dilakukan melalui analisis secara statistik dengan mempertimbangkan harga $r$, adjusted $r^{2}$, PRESS, dan $F_{\text {hit }} F_{\text {tab. }}$. Model-model persamaan yang terpilih kemudian diuji validitasnya dengan senyawa uji (senyawa $3,5,17$, dan 20) melalui perhitungan harga bioaktivitas $\left(-\log \mathrm{IC}_{50}\right.$ prediktif) keempat senyawa tersebut. Harga -log $\mathrm{IC}_{50}$ prediktif selanjutnya di-plot-kan dengan -log $\mathrm{IC}_{50}$ eksperimen untuk menentukan model persamaan HKSA yang terbaik. Langkah terakhir ini ditentukan dari parameter statistik yang meliputi slope dan $r^{2}$.

\subsection{Desain Senyawa Baru}

Model persamaan HKSA yang terbaik digunakan mendesain senyawa turunan triazolopiperazin amida yang baru. Langkah ini dilakukan dengan memodifikasi tipe dan letak substituent pada senyawa induknya. Semua kandidat senyawa baru yang dihasilkan selanjutnya digambar dan dioptimasi menggunakan Hyperchem 8.0 dengan metode semiempirik hasil validasi metode.

Seperti langkah sebelumnya, senyawasenyawa baru ini juga dihitung parameter elektronik dan molekuler yang akan digunakan untuk menentukan harga -log $\mathrm{IC}_{50}$ prediktifnya menggunakan persamaan HKSA terbaik sebelumnya. Secara statistik, senyawa baru layak diusulkan jika harga -log $\mathrm{IC}_{50}$ prediktifnya lebih besar dari harga -log $\mathrm{IC}_{50}$ senyawa sebelumnya dan harga PRESS kecil. Secara kimiawi, senyawa baru yang diusulkan juga harus memungkinan untuk disintesis.

\section{Tabel 2.}

Data panjang ikatan antar-atom dalam satuan $\AA$ senyawa triazolopiperazin amida hasil pemodelan dengan berbaqai metode perhitunqan

\begin{tabular}{lccccc}
\hline \multirow{2}{*}{ Ikatan } & \multicolumn{5}{c}{ Metode Komputasi } \\
\cline { 2 - 6 } & Ab initio & CNDO & MNDO & AM1 & PM3 \\
\hline C1-C7 & 1,531 & 1,467 & 1,516 & 1,488 & 1,495 \\
C7-C8 & 1,556 & 1,484 & 1,561 & 1,541 & 1,538 \\
C8-C9 & 1,557 & 1,483 & 1,560 & 1,539 & 1,533 \\
C9-C10 & 1,553 & 1,477 & 1,532 & 1,514 & 1,514 \\
10-N11 & 1,461 & 1,434 & 1,457 & 1,401 & 1,482 \\
C8-N24 & 1,494 & 1,425 & 1,475 & 1,456 & 1,492 \\
C10-025 & 1,218 & 1,322 & 1,222 & 1,246 & 1,213 \\
\hline
\end{tabular}

Tabel 3.

Sudut ikatan antaratom dalam satuan derajat $\left({ }^{\circ}\right)$ senyawa triazolopiperazin amida hasil pemodelan dengan berbagai metode perhitungan

\begin{tabular}{lccccc}
\hline \multirow{2}{*}{ Ikatan } & \multicolumn{5}{c}{ Metode Komputasi } \\
\cline { 2 - 6 } & Ab initio & CNDO & MNDO & AM1 & PM3 \\
\hline C1-C7-C8 & 112,59 & 111,41 & 115,51 & 111,87 & 111,77 \\
C7-C8-C9 & 113,59 & 113,74 & 116,10 & 108,74 & 112,74 \\
C8-C9-C10 & 117,82 & 112,45 & 116,56 & 110,48 & 116,93 \\
C9-C10-N11 & 116,29 & 116,58 & 115,75 & 120,56 & 117,36 \\
C7-C8-N24 & 110,00 & 110,78 & 110,36 & 112,00 & 108,53 \\
C9-C8-N24 & 109,62 & 107,81 & 108,50 & 110,97 & 111,77 \\
C9-C10-O25 & 112,69 & 118,32 & 125,26 & 119,74 & 123,86 \\
N11-C10-O25 & 120,49 & 117,51 & 118,98 & 119,52 & 118,70 \\
\hline
\end{tabular}


Tabel 4.

Asmara et al., ALCHEMY: Journal of Chemistry, $5: 4$ (2017) 106-113

Data muatan atom bersih dalam satuan Mulliken senyawa triazolopiperazin amida hasil pemodelan dengan berbagai metode perhitungan

\begin{tabular}{cccccc}
\hline \multirow{2}{*}{ Atom } & \multicolumn{5}{c}{ Metode Komputasi } \\
\cline { 2 - 6 } & Ab initio & CNDO & MNDO & AM1 & PM3 \\
\hline C7 & $-0,1105$ & 0,0130 & 0,0482 & $-0,1257$ & $-0,0627$ \\
C8 & 0,0587 & 0,1541 & 0,0644 & $-0,0220$ & $-0,0653$ \\
C9 & $-0,1293$ & $-0,0528$ & 0,0116 & $-0,1700$ & $-0,1204$ \\
C10 & 0,2887 & 0,3622 & 0,3704 & 0,3082 & 0,2973 \\
\hline
\end{tabular}

\section{Hasil dan pembahasan}

\subsection{Validasi Metode}

Hasil perhitungan metode semiempirik yang mendekati perhitungan metode ab initio dijadikan dasar untuk pemilihan metode semiempirik yang tepat dalam optimasi senyawa turunan triazolopiperazin amida yang akan diteliti. Hasil perhitungan panjang ikatan, sudut ikatan antar atom, dan muatan atom bersih dengan metode $a b$ initio dan empat metode semiempirik ditunjukkan pada Tabel 2, 3, dan 4.

Berdasarkan Tabel 2 dan 3, hasil perhitungan panjang ikatan dan sudut ikatan antar atom dari keempat metode semiempirik hampir mendekati hasil perhitungan dengan metode ab initio walaupun ada beberapa hasil perhitungan yang berbeda. Perbedaan yang terjadi dari perhitungan tersebut tidak signifikan. Untuk membantu memutuskan metode semiempirik mana yang lebih tepat dalam optimasi geometri senyawa turunan triazolopiperazin amida, hasil perhitungan muatan atom bersih untuk keempat metode semiempirik dibandingkan dengan hasil perhitungan dengan metode ab initio.

Berdasarkan Tabel 4, harga muatan keempat metode semiempirik relatif bervariasi terhadap hasil perhitungan metode ab initio. Pada atom $\mathrm{C} 7$, hasil perhitungan muatan dengan metode AM1 dan PM3 menunjukkan hasil yang paling mendekati perhitungan metode ab initio. Dilihat dari tandanya, kedua metode ini menunjukkan kesamaan dengan tanda muatan hasil perhitungan metode ab initio. Di sisi lain, metode CNDO dan MNDO memberikan tanda yang berbeda dengan hasil perhitungan metode ab initio. Pada atom $\mathrm{C} 8$, metode CNDO dan MNDO menunjukkan hasil perhitungan yang mendekati hasil perhitungan metode $a b$ initio yang dilihat dari kesamaan tanda. Untuk atom C9, hanya metode MNDO yang menunjukkan hasil berbeda dengan perhitungan metode $a b$ initio dari segi tanda.
Metode CNDO, AM1, dan PM3 memberikan hasil yang sama. Dilihat dari segi numerik, metode AM1 dan PM3 yang mendekati hasil perhitungan metode ab initio. Untuk atom C10, keempat metode semiempirik memberikan hasil yang sama dengan metode ab initio dari segi tanda. Namun, secara numerik, hanya metode AM1 dan PM3 yang mendekati hasil perhitungan metode ab initio.

Dari hasil perhitungan muatan atom bersih, metode semiempirik yang lebih mendekati hasil perhitungan metode $a b$ initio adalah metode AM1 dan PM3. Dari empat atom $C$ yang diuji, kedua metode ini memberikan hasil perhitungan untuk tiga atom $\mathrm{C}$ yang mendekati hasil perhitungan metode $a b$ initio. Jumlah data yang relatif sama dengan data $a b$ initio dari metode AM1 dan PM3 lebih banyak daripada data perhitungan metode CNDO dan MNDO. Secara teoritis, metode AM1 dan PM3 juga lebih disukai karena kedua metode ini merupakan hasil parameterisasi metode sebelumnya. Kedua metode ini juga tepat digunakan untuk senyawa organik yang mengandung gugus fenil di dalamnya (Pranowo, 2003).

\subsection{Analisis HKSA}

Model persamaan HKSA metode PM3 yang diperoleh dari analisis regresi multilinear disajikan pada Tabel 5. Tabel tersebut menunjukkan bahwa terjadi pengurangan jumlah variabel. Berdasarkan jumlah variabel yang ideal untuk persamaan yang baik, model 4, 5, dan 6 yang masuk dalam kandidat persamaan terbaik. Namun berdasarkan harga $F_{\text {hit }} / F_{\text {tab }}$, hanya model 5 dan 6 yang layak diajukan sebagai persamaan yang terbaik.

Rincian persamaan yang berasal dari model 5 dan 6 sebagai berikut.

a. Model 5 :

$-\log \mathrm{IC}_{50}=79,955-\left(11,635^{*} \mathrm{qC} 1\right)-\left(2,094^{*} \mathrm{qC} 2\right)-$ $\left(34,6^{*} \mathrm{qN} 11\right)+\left(797,684^{*} \mathrm{qC} 15\right)+\left(0,288^{*} \mu\right)$

$\left(\mathrm{n}=18 ; \mathrm{r}=0,714 ;\right.$ adjusted $r^{2}=0,305 ; \mathrm{F}_{\text {hil }} \mathrm{F}_{\mathrm{tab}}=$ 1,239; PRESS $=0,017$ )

b. Model 6 : 
$-\log \mathrm{IC}_{50}=77,654-\left(6,594^{*} \mathrm{qC} 1\right)-\left(41,308^{*} \mathrm{qN} 11\right)+$ $\left(781,078^{*} q C 15\right)+\left(0,318^{*} \mu\right)$

$\left(\mathrm{n}=18 ; \mathrm{r}=0,661 ;\right.$ adjusted $\mathrm{r}^{2}=0,263 ; \mathrm{F}_{\text {hit }} \mathrm{F}_{\mathrm{tab}}=$ 1,$004 ;$ PRESS $=3,423 \times 10^{-6}$ )

Kedua model tersebut lebih layak diajukan sebagai model persamaan HKSA metode PM3 yang terbaik karena jumlah variabelnya sedikit, harga PRESS yang diberikan kecil, dan harga $F_{\text {hit }} F_{\text {tab }}$ juga besar. Dari model 5 dan 6 , pemilihan model persamaan yang terbaik dilakukan uji validasi dengan menggunakan empat senyawa uji yang telah ditentukan sebelumnya. Uji validasi dilakukan dengan memprediksi aktivitas inhibasi menggunakan kedua model tersebut seperti yang terlihat pada Tabel 6, kemudian membuat kurva hubungan -log $\mathrm{IC}_{50}$ eksperimen dengan - $\log \mathrm{IC}_{50}$ prediktif seperti yang disajikan pada Gambar 2 dan 3. menunjukkan persamaan tersebut berkategori baik. Dari gambar tersebut, model persamaan terbaik adalah model 5. Hal ini ditunjukkan oleh parameter statistiknya lebih baik daripada model 6 .

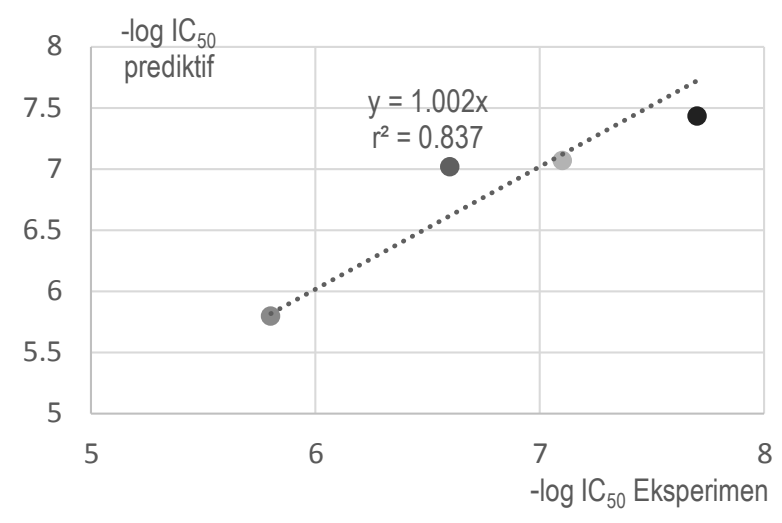

Gambar 2. Kurva -log $I C_{50}$ eksperimen vs $-\log \mathrm{IC}_{50}$ prediktif untuk model 5

\section{Tabel 5.}

Daftar parameter elektronik dan molekuler terpilih dari enam model hasil analisis regresi multilinear

\begin{tabular}{|c|c|c|c|c|c|c|c|c|c|}
\hline Model & Parameter & $r$ & $r^{2}$ & $\begin{array}{c}\text { Adjusted } \\
\mathrm{r}^{2}\end{array}$ & SD & $F_{\text {hitung }}$ & $\mathrm{F}_{\text {tabel }}$ & $F_{\text {hit }} / F_{\text {tab }}$ & PRESS \\
\hline 1 & $\begin{array}{l}\text { qC1, qC2, qN11, } \\
q C 15, q C 16, q O 25, \\
\mu, \text { SurGrid, } \log P\end{array}$ & 0,727 & 0,528 & $-0,002$ & 0,508 & 0,996 & 3,388 & 0,294 & 13,515 \\
\hline 2 & $\begin{array}{l}q C 1, q C 2, q N 11, \\
q C 15, q C 16, q 025, \\
\mu, \log P\end{array}$ & 0,726 & 0,527 & 0,107 & 0,369 & 1,255 & 3,229 & 0,389 & 1090,395 \\
\hline 3 & $\begin{array}{l}\text { qC1, qC2, qN11, } \\
\text { qC15, qO25, } \mu, \log \\
P\end{array}$ & 0,721 & 0,520 & 0,184 & 0,256 & 1,546 & 3,135 & 0,493 & $2,812 \times 10^{-5}$ \\
\hline 4 & $\begin{array}{l}q C 1, q C 2, q N 11, \\
q C 15, \mu, \log P\end{array}$ & 0,715 & 0,512 & 0,245 & 0,165 & 1,920 & 3,095 & 0,620 & 0,021 \\
\hline 5 & $\begin{array}{l}q C 1, q C 2, q N 11, \\
q C 15, \mu\end{array}$ & 0,714 & 0,509 & 0,305 & 0,090 & 3,848 & 3,106 & 1,239 & 0,017 \\
\hline 6 & $q C 1, q N 11, q C 15, \mu$ & 0,661 & 0,436 & 0,263 & 0,092 & 3,192 & 3,179 & 1,004 & $3,423 \times 10^{-6}$ \\
\hline
\end{tabular}

\section{Tabel 6.}

Data perbandingan aktivitas inhibasi eksperimen dan prediksi yang dihitung dengan model 5 dan 6

\begin{tabular}{cccc}
\hline Senyawa & $\begin{array}{c}-\log \mathbf{I} \mathbf{C}_{50} \\
\text { Uji }\end{array}$ & \multicolumn{2}{c}{$-\log \mathbf{I} \mathbf{C}_{50}$ prediksi } \\
\cline { 3 - 4 } eksperimen & Model 5 & Model 6 \\
\hline 3 & 6,6 & 7,020 & 6,954 \\
5 & 7,1 & 7,070 & 7,089 \\
17 & 5,8 & 5,795 & 5,476 \\
20 & 7,7 & 7,433 & 7,230 \\
\hline
\end{tabular}

Kurva yang memiliki harga $-\log \mathrm{IC}_{50}$ prediktif mendekati - $\log \mathrm{IC}_{50}$ eksperimen akan mempunyai harga slope dan $r^{2}$ yang mendekati satu. Harga ini

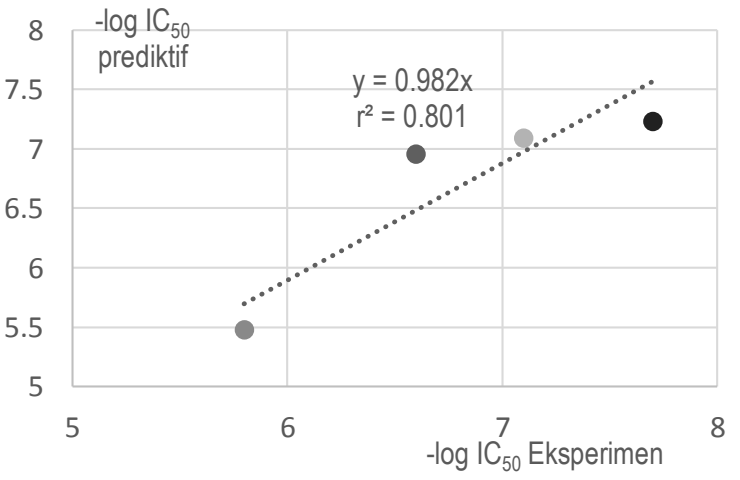

Gambar 3. Kurva -log $I C_{50}$ eksperimen vs $-\log \mathrm{IC}_{50}$ prediktif untuk model 6 


\subsection{Desain Senyawa Baru}

Model persamaan HKSA terbaik, model 5, digunakan untuk memprediksi bioaktivitas senyawa-senyawa baru hasil modifikasi menggunakan data deskriptornya. Data tersebut diperoleh dari optimasi geometri molekulnya kemudian dipilih parameter-parameter yang bersesuaian dengan model 5 , yaitu $q \mathrm{C} 1, \mathrm{qC} 2$, qN11, qC15, dan $\mu$. Parameter-parameter tersebut menentukan bioaktivitas senyawa-senyawa baru yang diusulkan. Harga -log $\mathrm{IC}_{50}$ prediktif senyawa baru disajikan pada Tabel 7 .

\section{Tabel 7.}

Daftar harga -log $\mathrm{IC}_{50}$ prediktif dari senyawasenyawa usulan hasil optimasi dengan metode semiempirik PM3

\begin{tabular}{|c|c|c|}
\hline No & $\mathbf{R}$ & $-\log I \mathrm{I}_{50}$ prediksi \\
\hline 24 & 2-F-4-NH & 7,834 \\
\hline 25 & 2-F-5-NH ${ }_{2}$ & 7,496 \\
\hline 26 & 2-F-6-NH 2 & 7,612 \\
\hline 27 & 2-F-4,6-di-NH 2 & 8,196 \\
\hline 28 & $2-\mathrm{F}-3-\mathrm{Br}$ & 6,978 \\
\hline 29 & $2-\mathrm{F}-4-\mathrm{Br}$ & 6,947 \\
\hline 30 & $2-\mathrm{F}-5-\mathrm{Br}$ & 7,173 \\
\hline 31 & $2-\mathrm{Cl}-5-\mathrm{CN}$ & 7,696 \\
\hline 32 & 2-Cl-3,5-di-CN & 6,926 \\
\hline 33 & 2-Cl-3-NH & 6,913 \\
\hline 34 & 2-Cl-4-NH & 7,798 \\
\hline 35 & 2-Cl-6-NH & 7,542 \\
\hline 36 & 2-Cl-4,6-di-NH ${ }_{2}$ & 8,118 \\
\hline 37 & 2-F-4-OH & 7,517 \\
\hline 38 & 2-F-6-OH & 8,268 \\
\hline 39 & 2-F-4,6-di-OH & 8,601 \\
\hline 40 & $2-\mathrm{F}-5-\mathrm{OH}$ & 6,616 \\
\hline
\end{tabular}

Sebanyak 17 senyawa baru hasil modifikasi substituen memberikan harga $-\log \mathrm{IC}_{50}$ prediktif yang beragam. Enam diantaranya memiliki harga bioaktivitas prediktif lebih baik dari senyawa sebelumnya $\left(-\log \mid \mathrm{C}_{50}>7,74\right)$. Kajian secara fisikokimia teoritis dilakukan untuk memprediksi tingkat kestabilannya baik secara individual maupun saat berinteraksi dengan reseptor.
Empat dari enam senyawa baru ini memiliki harga - $\log \mid \mathrm{C}_{50}>8$. Kecuali senyawa no. 38, senyawa no. 27, 36, dan 39 memiliki substituen di C2, C4, dan C6. Senyawa no. 38 hanya memiliki substituen di C2 dan C6. Hal ini menunjukkan bahwa substituen yang elektronegatif pada atom C2, C4, dan C6 akan mengurangi muatan negatif atom $\mathrm{C}$ tersebut dan menaikkan muatan negatif atom $\mathrm{C}$ tetangga $(\mathrm{C} 1, \mathrm{C} 3$, dan $\mathrm{C} 5)$.

Setelah dibandingkan dengan muatan atomatom C di senyawa terbaik sebelumnya, hasil perhitungan ini sesuai dengan keadaan optimal senyawa turunan triazolopiperazin amida yang telah diproduksi massal. Keadaan ini mempengaruhi muatan substituen yang terikat di gugus fenil menjadi dekat dengan awan elektron. Semakin dekat dengan awan elektron dengan kata lain makin negatif substituen maka makin kuat jaringan ikatan hidrogen yang dibentuk dengan kantong S1. Hal ini menyebabkan makin tinggi tingkat inhibisinya terhadap aktivitas DPP IV.

Keenam senyawa dengan bioaktivitas yang sangat memuaskan ini memiliki jenis substituen yang berbeda-beda. Senyawa no.39 dengan bioaktivitas prediksi terbaik $\left(-\log \mathrm{IC}_{50}=8,601\right)$ memiliki substituen 2-F-4,6-di-OH. Senyawa ini mengandung substituen optimal 2-F yang dilengkapi dua gugus $\mathrm{OH}$ yang akan membentuk ikatan hidrogen yang kuat dan memenuhi kantung S1 dengan ukurannya yang relatif lebih besar dari atom halogen. Senyawa no. 38 memiliki bioaktivitas prediksi sedikit di bawahnya $\left(-\log \mathrm{IC}_{50}=\right.$ 8,268 ) hanya memiliki substituen $2-\mathrm{F}$ dan $6-\mathrm{OH}$. Penurunan harga bioaktivitas ini dimungkinkan karena tidak dipasangnya substituen di C4 sehingga kantung S1 kurang terisi penuh.

Senyawa no. 27 dengan harga $-\log \mathrm{IC}_{50}=$ 8,196 memiliki substituen 2-F-4,6-di- $\mathrm{NH}_{2}$. Penurunan harga bioaktivitas prediktif senyawa ini dimungkinkan karena berkurangnya kemampuan gugus $-\mathrm{NH}_{2}$ untuk membentuk jaringan ikatan hidrogen yang kuat dengan kantong $\mathrm{S} 1$. Elektronegativitas atom $\mathrm{N}$ lebih rendah dibandingkan atom $\mathrm{O}$ sehingga kekuatan ikatan hidrogen yang terbentuk juga lebih lemah. Senyawa no. 36 yang memiliki substituen 2-Cl-4,6di-NH$H_{2}$ memberikan harga $-\log I_{50}=8,118$. Bioaktivitas prediktifnya sedikit turun karena penggantian atom $\mathrm{F}$ dengan atom $\mathrm{Cl}$ yang harga keelektronegatifannya lebih rendah.

Senyawa berikutnya adalah no. 24 dengan substituen 2-F-4-NH ${ }_{2}$ yang memiliki harga -log 
$I_{50}=7,834$. Berkurangnya bioaktivitas prediktif senyawa ini selain ikatan hidrogennya lebih lemah keempat senyawa di atasnya juga karena berkurangnya kemampuan substituennya untuk memenuhi kantung S1. Senyawa terbaik yang terakhir adalah senyawa no. 34 dengan harga -log $\mathrm{IC}_{50}=7,798$. Senyawa ini memberikan gaya antarmolekul yang paling lemah dibandingkan lima senyawa terbaik lainnya karena adanya substituen $\mathrm{Cl}$ yang elektronegativitasnya lebih kecil daripada atom $\mathrm{N}, \mathrm{O}$, dan $\mathrm{F}$.

Dilihat dari ukurannya, substituen-substituen ($\mathrm{NH}_{2}$ dan $-\mathrm{OH}$ ) yang diusulkan pada senyawasenyawa terbaik di atas termasuk spesies yang relatif kecil (nonbulky). Ukuran kedua gugus ini relatif lebih kecil dibandingkan gugus elektronegatif lainnya, seperti: -NHR, -OR, -SR, - $\mathrm{CF}_{3}$, dan $-\mathrm{R}$ (alkil). Pemilihan kedua gugus ini sesuai dengan petunjuk yang disampaikan oleh Saqib dan Siddiqi (2009) bahwa substituen nonbulky pada cincin fenil akan meningkatkan aktivitas inhibasi senyawa turunan triazolopiperazin amida. Kajian lebih lanjut tentang rute sintesis yang mungkin untuk senyawasenyawa baru tersebut perlu dilakukan baik secara teoritis maupun empiris untuk mengembangkan obat anti T2DM yang lebih kompetitif.

\section{Kesimpulan}

Penelitian ini berhasil membuktikan bahwa terdapat hubungan antara struktur senyawa turunan triazolopiperazin amida dengan bioaktivitasnya yang dikaji dengan metode semiempirik PM3. Melalui analisis regresi mulitilinear, hubungan tersebut dinyatakan dalam persamaan:

$-\log \mathrm{IC}_{50}=79,955-\left(11,635^{*} \mathrm{qC} 1\right)-\left(2,094^{*} \mathrm{qC} 2\right)-$ $\left(34,6^{*} \mathrm{qN} 11\right)+\left(797,684^{*} \mathrm{qC} 15\right)+\left(0,288^{*} \mu\right)$

$\left(\mathrm{n}=22 ; \mathrm{r}=0,714 ;\right.$ adjusted $\mathrm{r}^{2}=0,305 ; \mathrm{F}_{\text {hit }} / \mathrm{F}_{\mathrm{tab}}=$ 1,239; PRESS $=0,017$ )

Berdasarkan model persamaan HKSA terbaik di atas, penelitian ini juga berhasil mengusulkan senyawa baru bioaktivitas prediktifnya lebih baik dari senyawa triazolopiperazin amida sebelumnya, yaitu -log $\mathrm{IC}_{50}=8,601$. Senyawa yang dimaksud adalah: (2R)-4-Okso-4-[3-(Trifluorometil)-5,6dihidro[1,2,4]triazolo[4,3-a]pirazin-7(8H)-il]-1-(2fluoro-4,6-dihidroksofenil)butan-2-amina

\section{Daftar pustaka}

Asmara, A.P., Mudasir, \& Siswanta, D. (2013). Studi QSAR senyawa turunan triazolopiperazin amida sebagai inhibitor enzim Dipeptidil Peptidase-IV (DPP IV) menggunakan metode semiempirik AM1. Berkala MIPA, 23(3), 288-296.

Kim, D., Wang, L., Beconi, M., Eiermann, G.J., Fisher, M.H., He, H., ... Weber, A.E. (2005). (2R)-4-Oxo-4-[3-(Trifluoromethyl)-5,6-

dihydro $[1,2,4]$ triazolo $[4,3$-a]pyrazin- $7(8 \mathrm{H})$ yl]-1-(2,4,5-trifluorophenyl) butan-2-amine: a potent, orally active dipeptidyl peptidase IV inhibitor for the treatment of type 2 diabetes. Journal of Medicinal Chemistry, 48(1), 141151.

Kowalchick, J.E., Leiting, B., Pryor, K.A.D., Marsilio, F., Wu, J.K., He, H., ... Kim, D. (2007). Design, synthesis, and biological evaluation of triazolopiperazin-based $\beta$-amino amides as potent, orally active dipeptidyl peptidase IV (DPP-4) inhibitors, Bioorganic \& Medicinal Chemistry Letters, 17(21), 5934-5939.

Lambert, P., \& Bingley, P.J. (2002). What is type 1 diabetes?. Medicine, 30(1): 1-5.

Monika, G., Sarbjot, S., \& Punam, G. (2009). Dipeptidyl peptidase-4 inhibitors: a new approach in diabetes treatment. International Journal of Drug Development \& Research, 1(1), 146-156.

Pranowo, H.D. (2003). Kimia Komputasi, Pusat Kimia Komputasi Indonesia-Austria, Kimia FMIPA UGM, Yogyakarta.

Saqib, U., \& Siddiqi, M.I. (2009). 3D-QSAR studies on triazolopiperazin amide inhibitors of dipeptidyl peptidase-IV as anti-diabetic agents. SAR QSAR in Environmental Research, 20(5-6), 519-535.

Gardner, D.G., \& Shoback, D. (2011). Greenspan's basic \& clinical endocrinology (9th ed.). New York: McGraw-Hill Medical.

Vilsbøll, T., Hare, K.J., Bagger, J.O., \& Knop, F.K. (2009). Glucagon-like peptide-1 and diabetes treatment. International Diabetes Monitor, 21(1), 1-7.

Wild, S., Roglic, G., Green, A., Sicree, R., \& King, $H$. (2004). Global prevalence of diabetes: estimates for the year 2000 and projections for 2030. Diabetes Care, 27(5), 1047-1053. 